\title{
A new suspected paedomorphic genus of net-winged beetles from the Atlantic Rainforest (Coleoptera, Elateroidea, Lycidae)
}

\author{
Vinicius S. Ferreira' \& Luiz Felipe Lima Silveira ${ }^{2}$ \\ 1 Montana State University (MSU), Montana Entomology Collection (MTEC). Bozeman, Montana, United States. \\ ORCID: http://orcid.org/0000-0001-8748-0358. E-mail: vinicius.sfb@gmail.com (corresponding author) \\ 2 Western Carolina University (WCU), Biology Department. Cullowhee, North Caroline, United States. \\ ORCID: http://orcid.org/0000-0002-0648-3993. E-mail:silveira.Ifl@gmail.com
}

\begin{abstract}
Lycidae are among the better studied groups in the superfamily Elateroidea, however despite the progress in the taxonomic understanding of the Neotropical fauna, much still remains unknown and undescribed in the region. The description of the new genus Xenolycus gen. nov., from Serra dos Órgãos, a subrange of the Serra do Mar mountain range, in the Atlantic Rainforest in Rio de Janeiro State, Brazil, contributes to the knowledge of the Neotropical Lycidae fauna. The new genus can be distinguished from all other known Calopterini and Neotropical Lycidae by the combination of a pronotum with a wide, deep and strongly visible longitudinal cell in the disc area, the filiform antennae, the dehiscent elytra with reticulation strongly reduced and bearing only two weakly developed elytral costae and the mouthparts partially reduced, with rudimentary, barely visible mandibles. The type species, Xenolycus costae sp. nov., is illustrated and diagnostic characters and a discussion on the tribal placement of the new genus are provided.
\end{abstract}

Key-Words. Leptolycini; Neotropical Region; Neoteny; Elateroidea; Rio de Janeiro.

\section{INTRODUCTION}

When comparing the chaotic situation in the taxonomic knowledge of Elateroidea beetles in the Neotropical region (e.g., Lampyridae with Photinus Laporte, Phengodidae with Cenophengus LeConte, Omethidae with Telegeusis Barber, to mention a few), Lycidae are among the better studied groups in this superfamily. In the past two decades many of the most specious tribes found in the Neotropical region have been reviewed (Calopterini and Platerodini) (Bocakova, 2001, 2005), some genera have been revised (e.g., Bocakova et al., 2012; Ferreira, 2016; Ferreira \& Ivie, 2018) and several new taxa described (e.g., Ferreira, 2015, 2016; Kazantsev, 2013, 2017), while several world level phylogenies and classifications have been proposed (Bocak \& Bocakova, 2008; Kazantsev, 2013; Masek et al., 2018; Kusy et al., 2019) helping to slowly, but steadily, elucidate the huge gap in taxonomic knowledge in this diverse but still understudied family of beetles. Despite the progress, much still remains unknown and some of the most diverse and abundant and specious groups of Lycidae in the Neotropical region, such as Calopteron Guérin-Méneville, 1830 (Lycinae, Calopterini) and Plateros Bourgeois,
1879 (Lycinae, Platerodini), to mention two very emblematic cases, are almost impossible to be identified at species level. The majority of recent taxonomic works in Neotropical Lycidae focus in relatively small and less diverse genera of Lycidae (e.g., Nascimento \& Bocakova, 2009; Ferreira \& Ivie, 2016).

Most of the challenges associated with the identification of previously described taxa in Lycidae are intimately related to the fact that most descriptions came from early entomologists from the $19^{\text {th }}$ and $18^{\text {th }}$ century, such as Maurice Pic (1866-1957), Henry S. Gorham (1839-1920), George R. Waterhouse (1815-1898) and others, authors known to be very succinct and, in many cases, even misleading in their descriptions and works - Pic's publications in particular (see Bocakova, 2001, p. 53). In addition, the taxonomic impediment plays a big role in this matter, as most type specimens and a significant portion of literature are currently inaccessible, lost or of difficult access in European collections, turning the identification of Lycidae a Herculean task.

During the course of LFS's doctoral research, VSF was approached to help with the identification of Lycidae present in his by-catch Malaise trap samples from the Serra dos Órgãos mountain 
range in Rio de Janeiro state, Brazil. The initial examination to that material caught VSF's attention, as among that material a single specimen, unique and completely unknown to him was spotted. An initial assessment indicated that the mysterious beetle was, indeed, an undescribed genus and species. However, because only one specimen of that beetle was available at the time, the author's decided to not go ahead with the description of the new taxon and wait until more material could be found. In the last couple of years, with the re-examination of LFS's samples by the authors and other colleagues, more specimens of the mysterious beetles were found, which motivated us to carry on with this description.

Herein we take this opportunity to report a new monospecific Lycidae genus from the Atlantic Rainforest in Rio de Janeiro, Brazil, tentatively placed in the tribe Calopterini (Lycinae) (see current definition in Bocakova, $2003,2005)$, one of the most diverse in number of genera and species and abundance in the Neotropical region (Bocakova, 2003, 2005). The new taxon is illustrated, diagnostic characters and a discussion on the tribal placement of the new genus are provided.

\section{MATERIAL AND METHODS}

Specimens were studied under a Leica ${ }^{\circledR}$ Wild M3C stereoscopic microscope with magnification up to $40 \times$.

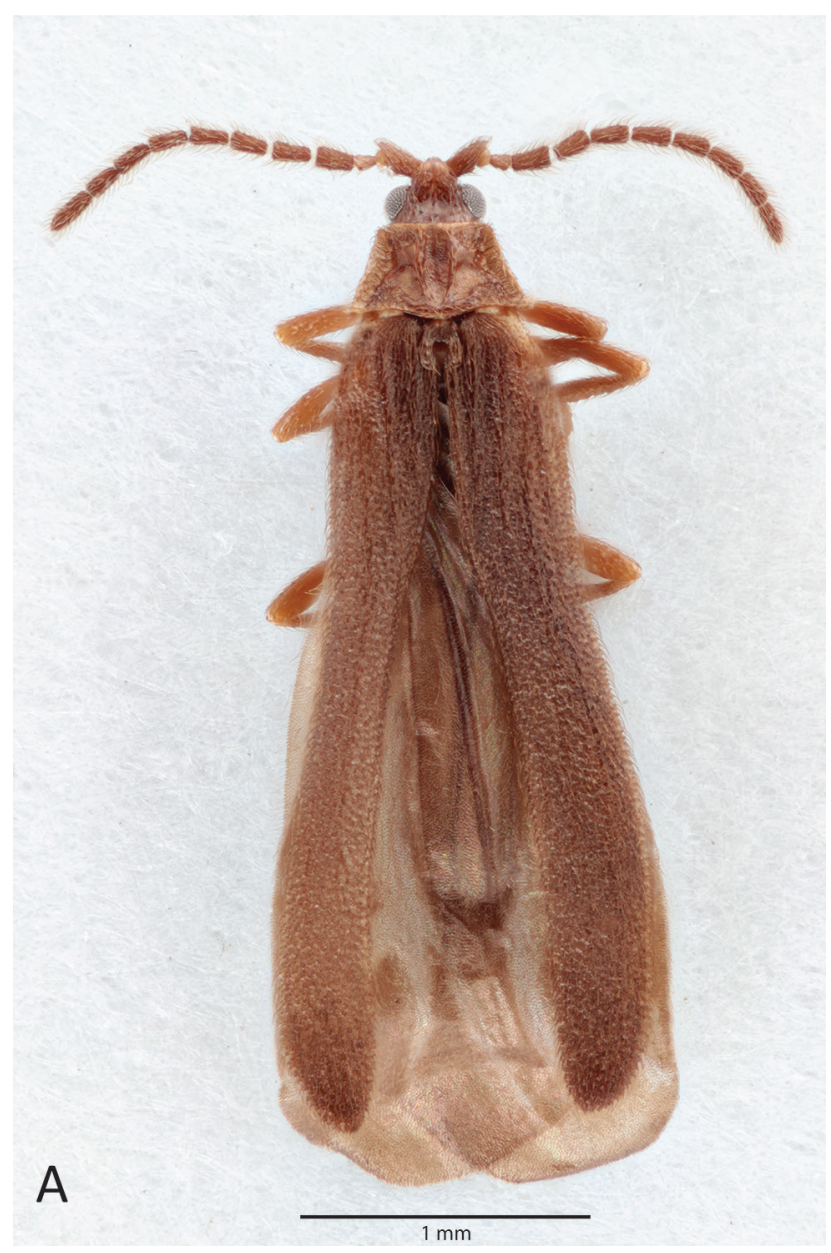

Figure 1. Xenolycus costae gen. nov. et sp. nov., male. (A) Dorsal habitus.
Photos were taken using a JVC (DC Ky-F75U) digital camera on a Leica ${ }^{\circledR}$ MS5 stereoscope and a Canon T3i DSLR with lenses MP-E 65 mm using a Stackshot ${ }^{\mathrm{TM}}$ - automated macro rail for focus stacking. Images were stacked using the software Zerene Stacker ${ }^{\circledR}$ software version 1.04 . Enhancements to digital images were made in Adobe Photoshop $^{\circledR}$ CC 2019. Drawings were prepared based on photographs using the Adobe Illustrator ${ }^{\circledR}$ CC 2019.

Morphological terminology follows Bocak \& Bocakova (1990), Kazantsev (2003) and Lawrence et al. (2011). Transcription of label data from specimens follows Ivie (1985): the end of each line on a label is indicated by a ";" (semicolon); the individual labels are separated by a "/" (slash). Specimens were collected in the Parque Nacional da Serra dos Órgãos (PARNASO), located at the Serra do Mar mountain range, in the Atlantic Rainforest of Southeastern Brazil (Roza et al., 2017). The examined material is permanently deposited in the following collections (respective curators are indicated in parentheses): MNRJ: Museu Nacional, Universidade Federal do Rio de Janeiro, Rio de Janeiro, Brazil (Marcela Monné); MTEC: Montana Entomology Collection, Montana State University, Bozeman, USA (Michael A. Ivie); MZSP: Museu de Zoologia, Universidade de São Paulo, São Paulo, Brazil (Sônia Casari).

\section{RESULTS}

\author{
Taxonomy \\ Family Lycidae Laporte, 1836 \\ Subfamily Lycinae Laporte, 1836 \\ Tribe Calopterini Green, 1949
}

\section{Genus Xenolycus gen. nov. (Figs. 1-2)}

Type species: Xenolycus costae sp. nov.

Differential diagnosis: Xenolycus gen.nov. can be distinguished from all other known Calopterini as defined in Bocakova $(2003,2005)$ and other Neotropical Lycidae, by the combination of pronotum with a wide, deep and strongly visible longitudinal cell in the disc area (Fig. 1), (vs. variable in other Calopterini genera, ranging from an absent cell in Calopteron Laporte and Mesopteron Bourgeois, or ranging from a slim and barely visible cell in Metapteron Bourgeois and Falsocaenia Pic, to a lenticular cell in Haplobothris Bourgeois, the latter never as wide or deep as in Xenolycus, absence of a cell in this conformation in all other Neotropical Lycidae), the filiform antennae, densely setose (Fig. 1) (vs. serrate or subserrate in the majority of other Neotropical Lycidae and Calopterini, Calopteron, Mesopteron, Metapteron, Falsocaenia and Haplobothris or flabellate in Acroleptus Bourgeois, Aporrhipis Pascoe, but filiform, shared with Neolyrium Kazantsev, and Tishechkinia Kazantsev and Electropteron Kazantsev, the last two currently in the Leptolycini), elytra dehiscent (vs. elytra shape variable across the Neotropical Lycidae genera, usually dehis- 
cent in groups known or suspected to be neotenous such as Ceratopriomorphus Pic), smooth, with reticulation strongly reduced (Fig. 1) (vs. strongly reticulate elytra in most Calopterini genera), with only two weakly developed and indistinct elytral costae (Fig. 2A) (vs. elytral costae usually strongly visible and easily identifiable in most Neotropical Lycidae, ranging from two to four costae, with the exception of Platerodini, which are usually absent), mouthparts partially reduced, labial palps two-segmented (vs. mostly three-segmented), with rudimentary, barely visible mandibles, seemingly absent (Fig. 2A) (vs. mandible developed in most genera, exceptions to some of the West Indies Leptolycini, such as Leptolycus Leng and Mutchler, also with seemingly absent mandibles), and by the maxillary palpomere II much longer (4X) than the precedent (Fig. 2A).

Description: General coloration and pubescence dark brown (Fig. 1A). Body setose, dorsal pubescence short and erect on elytra, remainder of body with fine pubescence throughout (Fig. 1A).

\section{Body}

Head: as long as wide, widest behind eyes, posteriorly partially covered by pronotum, hypognathous, frons slightly concave and elongate, acuminate at apex (Fig. 2A). Eyes hemispherical, projecting anterolaterally when viewed dorsally; coarsely granulate.

Mouthparts: Maxillary palp four-segmented, setose; palpomeres I, III and IV short, subequal in length, II very long, $4 \times$ the length of the precedent, last palpomere acuminate (Fig. 2A). Labial palp two-segmented, terminal segment, acuminate, setose, the precedent half the length of the II (Fig. 2A). Mandibles vestigial, barely visible, seemingly absent (Fig. 2A). Posterior margin of epistoma emarginate, labrum indistinct from clypeus (Fig. 2A).

Antennae: filiform, inserted in gibbous prominence at anterior portion of head, 11-segmented, connected by thin translucid membranes (Fig. 1A), in resting position reaching basal third of elytra, densely setose, bristled; scape subconic, pedicel short, flagellomere III twice the length of the pedicel; IV-X subequal in length and shape, $\mathrm{XI}$ roundish apically (Figs. $1 \mathrm{~A}$ ).

Prothorax: Pronotum transverse, trapezoidal; margins prominent; anterior angles round, posterior angles moderately acute (Fig. 1A); pronotum with a wide, deep and strongly visible longitudinal cell in the disc area, with two transversal oblique costae at middle (Fig. 1A). Hypomeron concave when viewed laterally. Prosternum Y-shaped, anterior margin with a flat rod-like structure (Fig. 2B).

Mesothorax: Mesoespiracles elongate, protuberant. Mesoventrite trapezoidal, posteriorly reaching anterior margin of metaventrite, connected to mesanepis- ternum by additional segment, mesepimeron more densely pubescent than surrounding sclerites (Fig. 2B). Scutellum protruded, posteriorly bifurcated, densely setose (Fig. 1A).

Metathorax: Metaventrite convex, posterolateral angles pronounced, acute; metadiscrimen incomplete, only present in apical third (Fig. 2B); metanepisternum and metepimeron elongate, widest in the middle (Fig. 2B).

Elytra: dehiscent, $6.5 \times$ longer than pronotum; smooth, with two elytral costae (I and II) weakly developed, only present in basal portion on each elytron, fading towards apex, secondary costae absent (Fig. 1A). Metathoracic wings with reduced venation, $\mathrm{Cu}$ veins absent (Fig. 2C).

Legs: slender, elongate; protrochantins slender and exposed (Fig. 2B); trochanters tubular; pro- and meso- femora and tibiae subequal in length, metafemora shorter than tibiae; femora sturdy, slightly fusiform; tibiae clavate, slender; pro- and mesocoxae conical, obliquely positioned, procoxae contiguous, metacoxae transverse (Fig. 2B); tarsal formula 5-5-5, all tarsomeres very narrow.

Abdomen of males with eight ventrites, densely setose; male genitalia symmetrical (Fig. 2D); median lobe slightly tapered towards apex, acuminate at the tip, $1 / 4$ longer than parameres (Fig. 2D); parameres rounded apically; phallobase subequal in length with parameres + median lobe, posterior margin round, median suture absent (Fig. 2D).

Females: unknown.

Length: 5.2-5.4 mm. Width (across humerus): 1.1-1.3 mm.

Etymology: The name is an allusion to the unique and strange appearance of this new genus. Xeno-, from the Greek, ६źvoc, meaning strange, alien, exotic or different, and Lycus, in allusion to type genus of the family Lycidae. Gender masculine.

Distribution: Xenolycus gen. nov. is only known to occur in Southeastern Brazil, in the Atlantic Rainforest, specifically in Serra dos Órgãos, a subrange of the Serra do Mar mountain range, in the municipality of Teresópolis, Rio de Janeiro State. The Serra do Mar is one of the main mountain ranges in Southeastern Brazil, and houses several endemic species of plants and animals, including elateroid beetles. In fact, several endemic species of fireflies (e.g., Silveira \& Mermudes, 2014; Silveira et al., 2016, 2018) and rail-road worms (e.g., Roza et al., 2017) have been found in the Serra do Mar, which seem to have very narrow geographic ranges, sometimes restricted to single mountaintops or foothills. In this context, Xenolycus gen. nov. stand out as the first prima facie endemic taxon net-winged beetle species in the Serra dos Órgãos region, piling up the evidence for the Serra do Mar being an important hotspot for soft-bodied elateroid beetles. 
Biology and immature: Unknown. Members of this genus are presumably paedomorphic (see discussion section).

Remarks: Taxonomic keys for Calopterini genera (Bocakova, 2003) are currently outdated and are not reliable nor appropriate for identifying Neotropical Lycidae genera without significant changes and improvements, and for this reason, the new genus was not included in any key nor any amendments to previously existing keys were provided. A key to all New World tribes and genera of Lycidae is in preparation and will be presented in a future publication.

\section{Xenolycus costae sp. nov.}

Type material: HOLOTYPE $0^{\prime \prime}$ (MZSP): BRAZIL: Rio de Janeiro; Teresópolis, PARNASO; 22²7'18.7"S,
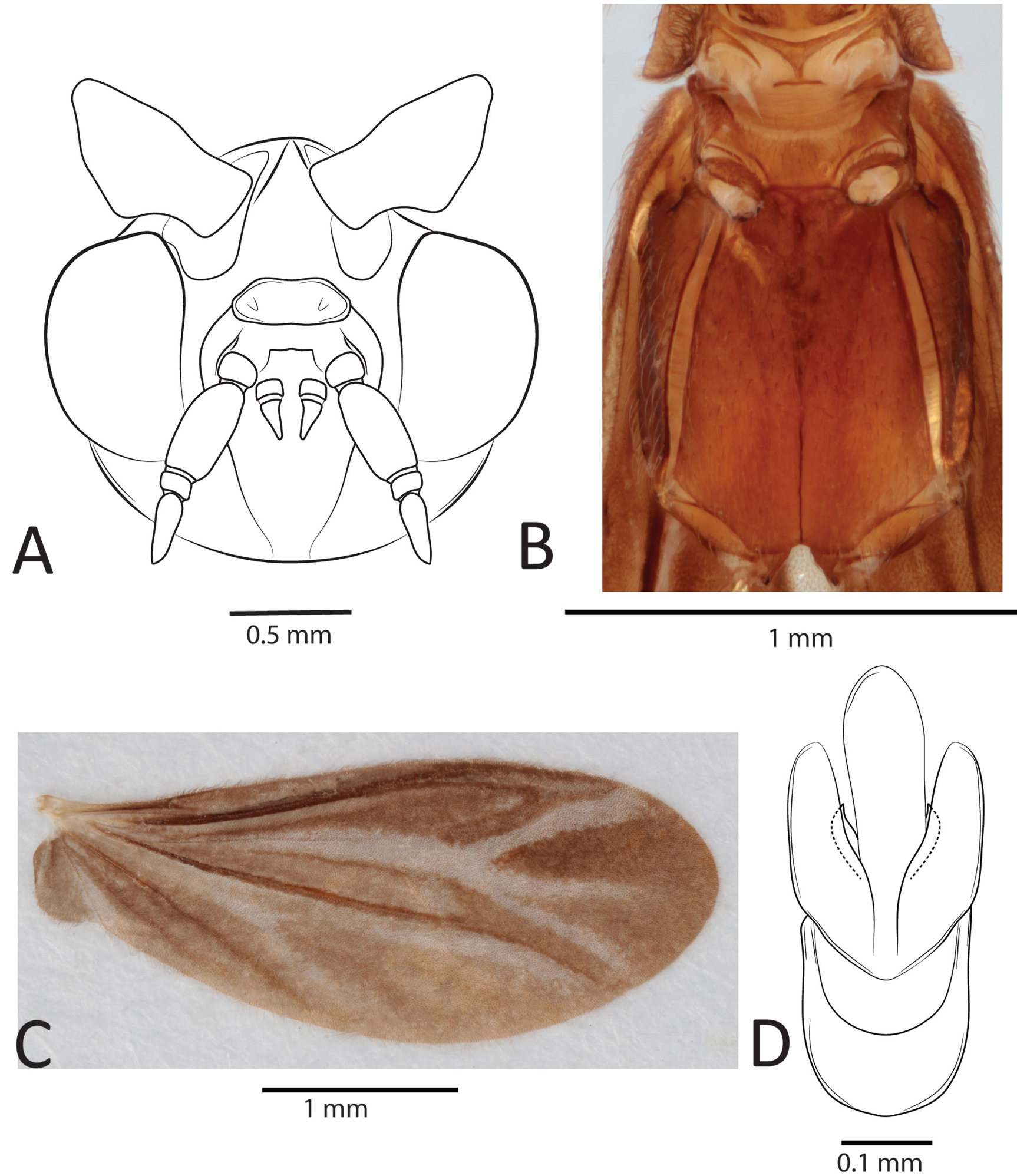

Figure 2. Xenolycus costae gen. nov. et sp. nov., male. (A) Head and mouthparts detail; (B) Ventral view of thorax; (C) Membranous wing; (D) Male genitalia, dorsal view. 
4301'32.0"W, 1,630 m; 29-IV-2013; Malaise trap; R. Monteiro, M. Macedo/ HOLOTYPE: Xenolycus costae; Ferreira \& Silveira 2020. PARATYPES (4): BRAZIL: Rio de Janeiro; Teresópolis, PARNASO; 22²7'34.6"S 430.'40.2"W, 1,824 m; 03-VIII-2013; Malaise trap; R. Monteiro, M. Macedo/ PARATYPE: Xenolycus costae; Ferreira \& Silveira 2020 (1 o', MZSP). Idem (1 o', MNRJ). BRAZIL: Rio de Janeiro; Teresópolis, PARNASO; $22^{\circ} 26^{\prime} 51.0^{\prime \prime} \mathrm{S}, 43^{\circ} 00^{\prime} 46.4^{\prime \prime} \mathrm{W}, 1,444 \mathrm{~m}$; IV-2015; Malaise trap; R. Monteiro, M. Macedo/ PARATYPE: Xenolycus costae; Ferreira \& Silveira 2020 (1 $\sigma^{\circ}$, MNRJ). BRAZIL: Rio de Janeiro; Teresópolis, PARNASO; 22²7'18.7"S, 4301'32.0"W, 1,630 m; 03-VIII-2013; Malaise trap; R. Monteiro, M. Macedo/ PARATYPE: Xenolycus costae; Ferreira \& Silveira 2020 (1 $\sigma^{\star}$, MTEC).

Description and diagnosis: The diagnosis and description for Xenolycus costae sp. nov. is redundant with the generic diagnosis, see above.

Etymology: The species was named in honor of Professor Cleide Costa, in the commemoration of her $80^{\text {th }}$ birthday. Professor Costa is one of the greatest Brazilian entomologists who dedicated her life to the study of Neotropical Elateridae, Coleoptera in general and immatures of Coleoptera during her prolific career in the Museu de Zoologia, Universidade de São Paulo. She was responsible for inspiring and mentoring generations of coleopterists and is a role model and an example of dedication, professionalism and devotion to coleopterology. This is a small tribute from the authors to our master.

Measurements, distribution and biology: See generic description.

\section{DISCUSSION}

\section{Taxonomic placement of Xenolycus gen.nov.}

Xenolycus gen. nov. is another lycid with a difficult tribal placement. The new genus possesses a general morphology that conforms with groups known or suspected to have a paedomorphic life strategies and extreme paedomorphic females: reduced mouthparts, sclerotization, wing venation, elytral striation and reticulation, and unknown females (VSF, unpublished data). The current delimitation in the taxonomy of the two potential tribes where Xenolycus gen.nov. could be placed, Calopterini and Leptolycini (Lycinae), is unresolved, as several genera in the former and all genera in the latter possess paedomorphic characteristics, and a detailed morphology comparison and study between members of both tribes have not been done.

Over the last years many classifications were proposed for the paedomorphic lineages of New World Lycidae, and in most cases with conflicting results (see Bocak \& Bocakova, 1990, 2008; Bocakova, 2014; Kazantsev, 2013, 2017). Recent multigene phylogenies (Masek et al., 2018; Kusy et al., 2019) support that both
Calopterini and Leptolycini are in fact separate monophyletic lineages, with the Calopterini sister to Lycini (ibidem), and Leptolycini as sister to Eurrhacini (Masek et al., 2018) or Platerodini (Kusy et al., 2019), however, not much has been discussed regarding their paedomorphic convergent morphology.

A common feature in both recent phylogenies is that the Leptolycini are restricted to the Greater Antilles, while the Calopterini are a mainland lineage. Even though these initial investigations using DNA data suggests separate lineages, the datasets are not comprehensive, and other controversial taxa, such as the genera and species recently described by Kazantsev (2017) and placed in the Leptolycini, or Cephalolycus Pic, 1926 (placed as incertae sedis Calopterini by Ferreira \& Ivie (2016) but moved to the Leptolycini by Kazantsev (2017)), and many other genera (see discussion in Ferreira \& Ivie (2018) and Ferreira et al. (2018)) have not been sampled in these studies.

Recent similar cases are reported in Ferreira \& Ivie (2016, 2018) and Ferreira et al. (2018), where the morphological delimitations between males of both tribes are discussed, but a definitive conclusion is yet to be published and discussed. Ferreira \& Ivie (2016), following Miller (1991), suggest that the shape of tarsomere IV is one of the deciding characters to separate Calopterini (broad and expanded) from Leptolycini (narrow), however recent observations (VSF, unpublished data) do not confirm this constant. In the absence of molecular data or other evidence to the contrary, and in light of the consistency of Masek et al. (2018) and Kusy et al. (2019) in recognizing true Leptolycini as endemic to the Greater Antilles, we place Xenolycus gen. nov. provisionally in the Calopterini.

\section{ACKNOWLEDGMENTS}

The authors thank André Roza (Universidade Federal do Rio de Janeiro) for sorting part of the Lycidae samples from their original Malaise traps, and to Ricardo Monteiro and Margarete Monteiro (Universidade Federal do Rio de Janeiro) for giving us access to the samples located in their laboratory and allowing their use in taxonomic studies. We are grateful to Gabriel Biffi and Sônia Casari (Museu de Zoologia, Universidade de São Paulo) for their invitation for this special issue and to the two anonymous reviewers for their comments, suggestions and corrections in this manuscript. The authors are thankful to Max Barclay (The Natural History Museum, London, England) for his help with the Greek roots of the generic name. VSF is very thankful to Erich L. Spiessberger and Lorena Santos for their help with the transport of specimens used in this study and to Michael Ivie (MTEC) for allowing the use of his lab space and to Felipe Francisco Barbosa (Universidade Federal do Rio de Janeiro) for his suggestions and comments in an earlier version of this manuscript. VSF is very grateful to Conselho Nacional de Desenvolvimento Científico e Tecnológico (CNPq) of Brazil for the scholarship (process 202559/2015-7) that allowed him to continue his study of the Lycidae and 
to the Idea Wild Project for providing resources that allowed the acquisition of the photographic equipment used in this project. We thank Serra dos Órgãos National Park for housing LFS during field work, which was supported by Fundação de Amparo à Pesquisa do Estado do Rio de Janeiro (FAPERJ) (process 101.476/2010) and CNPq (process 470980/2011-7).

\section{REFERENCES}

Bocak, L. \& Bocakova, M. 1990. Revision of the suprageneric classification of the family Lycidae (Coleoptera). Polskie Pismo Entomologiczne, 59(4): 623-676.

Bocak, L. \& Bocakova, M. 2008. Phylogeny and Classification of the Family Lycidae (Insecta: Coleoptera). Annales Zoologici, 58(4): 695-720. D0I

Bocakova, M. 2001. Revision and phylogenetic analysis of the subfamily Platerodinae (Coleoptera: Lycidae). European Journal of Entomology, 98(1): 53-85.

Bocakova, M. 2003. Revision of the tribe Calopterini (Coleoptera, Lycidae). Studies on Neotropical Fauna and Environment, 38(3): 207-234.

Bocakova, M. 2005. Phylogeny and classification of the tribe Calopterini (Coleoptera, Lycidae). Insect Systematics and Evolution, 35(4): 437-447.

Bocakova, M. 2014. Lolodorfus, a new genus of net-winged beetles (Coleoptera: Lycidae: Dexorinae) from Cameroon. Zootaxa, 3811(3): 374-380.

Bocakova, M.; Barancikova, B. \& Nascimento, E.A. 2012. Revision of the genus Falsocaenia (Coleoptera: Lycidae). Zootaxa, 3478(1): 282-296.

Ferreira, V.S. 2015. A new species of Acroleptus Bourgeois (Coleoptera: Lycidae) from the Brazilian Amazonian rainforest, with a note on its homonymy with Acroleptus Cabanis (Aves). Zootaxa, 3949(2): 297-300.

Ferreira, V.S. 2016. A revision of the genus Macrolygistopterus Pic, 1929 (Coleoptera, Lycidae, Calochromini). Zootaxa, 4105(4): 321-338.

Ferreira, V.S. \& Ivie, M.A. 2016. Redescription of Cephalolycus major Pic, 1926 (Coleoptera: Elateroidea: Lycidae) and a discussion on its taxonomic position. The Coleopterists Bulletin, 70(3): 663-666.

Ferreira, V.S. \& Ivie, M.A. 2018. A revision of Lycinella Gorham, 1884 with the description of six new species (Coleoptera, Lycidae, Calopterini). ZooKeys, 792: 69-89.

Ferreira, V.S.; Barclay, M.V.L. \& Ivie, M.A. 2018. Redescription of Aporrhipis Pascoe, 1887 (Coleoptera: Lycidae), with a discussion of its tribal placement. The Coleopterists Bulletin, 72(2): 371-375.
Ivie, M.A. 1985. Nomenclatural notes on West Indian Elaphidiini (Coleoptera: (erambycidae). Pan-Pacific Entomologist, 61(4): 303-314.

Kazantsev, S.V. 2003. Morphology of Lycidae with some considerations on evolution of the Coleoptera. Elytron, 17: 49-226.

Kazantsev, S.V. 2013. New and little-known taxa of "neotenic" Lycidae (Coleoptera), with discussion of their phylogeny. Russian Entomological Journal, 22 (1): 9-31.

Kazantsev, S.V. 2017. New leptolycines from Ecuador and Peru (Coleoptera: Lycidae). Russian Entomological Journal, 26(2): 127-146.

Kusy, D.; Motyka, M.; Bocek, M.; Masek, M. \& Bocak, L. 2019. Phylogenomic analysis resolves the relationships among net-winged beetles (Coleoptera: Lycidae) and reveals the parallel evolution of morphological traits. Systematic Entomology, 44(4): 911-925.

Lawrence, J.F.; Slipinski, A.; Seago, A.E.; Thayer, M.K.; Newton, A.F. \& Marvaldi, A.E. 2011. Phylogeny of the Coleoptera based on morphological characters of adults and larvae. Annales Zoologici, 61(1): 1-217.

Masek, M.; Motyka, M.; Kusy, D.; Bocek, M.; Li, Y. \& Bocak, L. 2018. Molecular phylogeny, diversity and zoogeography of net-winged beetles (Coleoptera: Lycidae). Insects, 9(4): 154.

Miller, R.S. 1991. A revision of the Leptolycini (Coleoptera: Lycidae) with a discussion of paedomorphosis. PhD thesis. The Ohio State University, U.S.A, $806 \mathrm{pp}$.

Nascimento, E.A. \& Bocakova, M. 2009. A revision of the genus Lycomorphon (Coleoptera: Lycidae). Zootaxa, 2132(1): 40-52.

Roza, A.S.; Quintino, H.Y.S.; Mermudes, J.R.M. \& Silveira, L.F.L. 2017. Akamboja gen. nov., a new genus of railroad-worm beetle endemic to the Atlantic Rainforest, with five new species (Coleoptera: Phengodidae, Mastinocerinae). Zootaxa, 4306(4): 501-523.

Silveira, L.; Khattar, G.; Souto, P.; Mermudes, J.R.M.; Takiya, D.M. \& Monteiro, R.F. 2016. Integrative taxonomy of new firefly taxa from the Atlantic Rainforest. Systematics and biodiversity, 14(4): 371-384.

Silveira, L.F.L. \& Mermudes, J.R.M. 2014. Ybytyramoan, a new genus of fireflies (Coleoptera: Lampyridae, Lampyrinae, Photinini) endemic to the Brazilian Atlantic Rainforest, with description of three new species. Zootaxa, 3835(3): 325-337.

Silveira, L.F.L.; Souto, P.M. \& Mermudes, J.R.M. 2018. Four new species of Luciuranus fireflies from the Brazilian Atlantic Rainforest (Coleoptera: Lampyridae). Zootaxa, 4413(1): 173-186. 